\title{
SUSCEPTIBILITY OF RATS TO EXPERIMENTAL PYELONEPHRITIS DURING POTASSIUM DEPLETION *
}

\author{
By JAMES W. WOODS, LOUIS G. WELT AND WALTER HOLLANDER, JR. $\dagger$ \\ (From the Department of Medicine, University of North Carolina School of Medicine, \\ Chapel Hill, N. C.)
}

(Submitted for publication September 7, 1960; accepted November 3, 1960)

It has been adequately shown that potassium depletion can produce functional and structural changes of the kidney both in the experimental animal and in man $(1,2)$. These changes are primarily tubular and may be partially or wholly reversible. Clinical data suggest an association between potassium nephropathy and pyelonephritis $(3-5)$, and there is evidence both for $(5,6)$ and against such an association in the experimental animal (7). If such an association were confirmed in the human, it would be one of the most serious of all of the consequences of potassium depletion. A recent study carried out in this laboratory clearly demonstrated increased susceptibility of rats to experimental pyelonephritis following recovery from potassium depletion (6). The present investigation was designed to study the susceptibility of rats to pyelonephritis during acute potassium depletion.

\section{MATERIALS AND METHODS}

White, male, Sprague-Dawley strain rats, weighing 184 to $264 \mathrm{~g}$ were used. Potassium depletion was produced by means of a basal diet deficient in potassium, sodium, phosphorus and chloride. Control groups received the following daily quantity of supplementary electrolytes by gavage: $5 \mathrm{ml}$ of gavage solution containing (in millimoles) 2 of potassium, 2 of sodium, 2.5 of chloride and 0.75 of phosphorus. The potassium-deficient groups received (in millimoles) 4 of sodium, 2 of bicarbonate, 0.5 of chloride and 0.75 of phosphorus. The method of producing potassium depletion, including content of diet, and the chemical methods used, have been previously described $(6,8)$. The animals were "pair-fed" by groups; i.e., the intake of the control groups was limited each day to the average intake of the experimental groups.

Experimental design. The experimental design is shown in Table I. After having been on a potassium-

* This investigation was supported by Grants H-3794 and H-1301 from the United States Public Health Service, Bethesda, Md., and by a grant from the American Heart Association.

$\dagger$ Markle Scholar in Medical Science. deficient regimen for 2 weeks, the animals of Group A were sacrificed for control analyses, while the animals of Groups B and C were injected with approximately 100 million Escherichia coli and continued on a modification of the original regimen which consisted of the same electrolyte-free diet and daily gavage with $5 \mathrm{ml}$ of a solution containing, in millimoles (for controls) 1 of sodium, 2 of potassium, 2.25 of chloride and 0.375 of phosphorus; and (for experimentals) 1 of sodium, 0.125 of chloride, 0.5 of bicarbonate, and 0.186 of phosphorus. This was done in order to maintain the potassium-deficient state without its becoming so severe as to cause death of animals.

Bacteriologic techniques. The strain of E. coli used for intravenous inoculation and the details of bacteriological techniques used were exactly the same as those previously described in detail (6). In addition to the studies of renal tissue, other organs were consistently inspected for evidence of infection, and samples of liver and lung from each animal were cultured. Animals of Group B were sacrificed 1 week after injection of $E$. coli, while those of Group C were sacrificed 3 weeks after injection. Sacrifice was so spaced because of the work load involved in dealing with the large number of animals; in addition, the time interval would provide the opportunity to determine whether bacterial multiplication in the kidney was increasing or decreasing during the postinjection period. Five experimentals and an equal number of controls from both Groups B and C had analyses of sera and skeletal muscle in order to document and determine the degree of potassium depletion.

TABLE I

Experimental design

\begin{tabular}{|c|c|c|c|}
\hline Group & Description & $\begin{array}{l}\text { No. of } \\
\text { exptl. } \\
\text { rats }\end{array}$ & $\begin{array}{l}\text { No. of } \\
\text { control } \\
\text { rats }\end{array}$ \\
\hline A & $\begin{array}{l}\text { K-depletion } 2 \text { wks; analysis of } \\
\text { renal histology, serum elec- } \\
\text { trolytes, muscle } K \text {; culture } \\
\text { for spontaneous infection }\end{array}$ & 5 & 5 \\
\hline B & $\begin{array}{l}\text { K-depletion } 2 \text { wks; sacrificed } 1 \\
\text { wk after injecting } 100,000,000 \\
E \text {. coli i.v.; analysis of serum } \\
\text { electrolytes and muscle } \mathrm{K} \text { in } \\
\text { a representative sample }\end{array}$ & 22 & 21 \\
\hline $\mathrm{C}$ & $\begin{array}{l}\text { K-depletion } 2 \text { wks; sacrificed } 3 \\
\text { wks after injecting } 100,000,000 \\
E \text {. coli i.v.; analysis of serum } \\
\text { electrolytes and muscle } K \text { in } \\
\text { a representative sample }\end{array}$ & 17 & 17 \\
\hline
\end{tabular}




\section{RESULTS}

Condition of animals. Six rats died as a result of gavage during the first week of the study and four were found dead in their cages during the first 48 hours after injection of $E$. coli. These were excluded from the study. The remainder appeared reasonably healthy and there was no difference between the final average weight of experimental and control groups (241 g vs 243 $\mathrm{g})$. The results of the chemical determinations are shown in Table II. Analyses of serum electrolytes of the three experimental groups as compared with their controls revealed a hypokalemic, hypochloremic alkalosis. Serum sodium concentrations remained normal. There was a moderate decrease in skeletal muscle potassium content when it was measured in terms of milliequivalents of potassium per $100 \mathrm{~g}$ of fat-free dry solids. The degree of potassium depletion increased slightly during the three week postinjection period as is seen in a comparison of the data from the three groups. As discussed by Oliver and co-workers (2), there appears to be an element of tubular obstruction in potassium nephropathy, and tubular dilatation consistent with this was microscopically evident at three and five weeks (Groups B and C). Tubular dilatation was not yet clearly evident at two weeks (Group A) when the animals were injected with $E$. coli. The results per- taining to renal infection are shown in Table III. Gross appearance, colony counts for the pooled halves of each of the kidneys, and microscopic appearance of the two remaining halves are presented. Ten of the 39 potassium-depleted animals, but only 1 of the 38 controls had the combination of gross abscess, colony count over 100,000 E. coli per $g$ of kidney, and unequivocal microscopic evidence of pyelonephritis $(p<0.02) .^{1} \quad$ Additionally, in the potassium-depleted groups: 2 animals had unequivocal microscopic evidence of pyelonephritis without gross or cultural evidence; 2 had macroscopic abscesses and high colony counts with only small round cell infiltrates microscopically; 2 had macroscopic scars combined with microscopic evidence of pyelonephritis (one of the latter had a high colony count of $E$. coli in the kidneys, while the other had a count of 1,400 E. coli per $g$ of kidney); and 1 had macroscopic and microscopic evidence of infection with a colony count of 4,000 E. coli per $g$ of kidney. In the control groups, 5 additional rats had positive evidence of infection in one or more of the three descriptive categories but not in all three. If all of these additional animals are included, 17 of 39 potassium-depleted and 6 of 38 controls had pyelonephritis $(p<0.02)$. Eleven of the ex-

$1 \mathrm{~A}$ chi-square test was used to calculate $\mathrm{p}$ values.

TABLE II

Analyses of sera and skeletal muscle

\begin{tabular}{|c|c|c|c|c|c|c|}
\hline \multirow[b]{3}{*}{ Group } & \multicolumn{3}{|c|}{ K-depleted } & \multicolumn{3}{|c|}{ Controls } \\
\hline & \multicolumn{2}{|c|}{ Serum } & \multirow{2}{*}{$\underset{\mathbf{K}}{\text { Muscle }}$} & \multicolumn{2}{|c|}{ Serum } & \multirow{2}{*}{$\underset{\mathbf{K}}{\text { Muscle }}$} \\
\hline & $\mathbf{K}$ & $\overline{\mathrm{CO}_{2}}$ & & $\mathbf{K}$ & $\mathrm{CO}_{2}$ & \\
\hline A & $\begin{array}{c}m E q / L \\
2.2 \\
3.1 \\
2.8 \\
3.5 \\
3.1\end{array}$ & $\begin{array}{c}m E q / L \\
27.5 \\
19.8 \\
26.1 \\
28.4 \\
27.0\end{array}$ & $\begin{array}{c}m E q / 100 \mathrm{~g} F F D S * \\
37.4 \\
41.1 \\
37.7 \\
37.5 \\
37.5\end{array}$ & $\begin{array}{c}m E q / L \\
3.8 \\
4.5 \\
4.1 \\
4.3 \\
4.1\end{array}$ & $\begin{array}{c}m E q / L \\
21.0 \\
24.5 \\
17.7 \\
23.1 \\
21.7\end{array}$ & $\begin{array}{c}m E q / 100 \mathrm{~g} F F D S * \\
43.9 \\
43.9 \\
47.6 \\
48.0 \\
47.2\end{array}$ \\
\hline B & $\begin{array}{l}3.0 \\
2.8 \\
4.1 \\
4.0 \\
3.3\end{array}$ & $\begin{array}{l}27.0 \\
34.2 \\
31.2 \\
35.2 \\
32.7\end{array}$ & $\begin{array}{l}35.8 \\
32.5 \\
42.6 \\
36.7 \\
39.7\end{array}$ & $\begin{array}{l}4.9 \\
5.4 \\
5.1 \\
5.0 \\
5.5\end{array}$ & $\begin{array}{l}23.8 \\
24.7 \\
25.5 \\
30.1 \\
25.8\end{array}$ & $\begin{array}{l}45.8 \\
47.7 \\
49.0 \\
46.7 \\
46.6\end{array}$ \\
\hline C & $\begin{array}{l}2.4 \\
2.4 \\
2.6 \\
3.2 \\
2.6\end{array}$ & $\begin{array}{l}32.8 \\
28.9 \\
33.5 \\
29.3 \\
30.4\end{array}$ & $\begin{array}{l}30.5 \\
34.1 \\
33.0 \\
39.7 \\
33.0\end{array}$ & $\begin{array}{l}4.1 \\
4.7 \\
4.9 \\
4.5 \\
4.1\end{array}$ & $\begin{array}{l}24.8 \\
26.7 \\
25.8 \\
21.2 \\
21.4\end{array}$ & $\begin{array}{l}44.3 \\
43.6 \\
45.2 \\
44.7 \\
45.7\end{array}$ \\
\hline
\end{tabular}

*FFDS = fat-free dry solids. 
TABLE III

Colony counts and description of kidneys after injection of E. coli

\begin{tabular}{|c|c|c|c|c|c|c|}
\hline \multirow[b]{2}{*}{ Group } & \multicolumn{3}{|c|}{ K-depleted } & \multicolumn{3}{|c|}{ Controls } \\
\hline & $\begin{array}{c}\text { Gross } \\
\text { appearance * }\end{array}$ & Colony count & $\begin{array}{l}\text { Micro- } \\
\text { scopic } \dagger\end{array}$ & $\begin{array}{c}\text { Gross } \\
\text { appearance }\end{array}$ & Colony count & $\begin{array}{l}\text { Micro- } \\
\text { scopic }\end{array}$ \\
\hline \multirow{15}{*}{ B } & & E. coli/g kidney & & & E. coli/g kidney & \\
\hline & $*$ & $4,600,000$ & $\dagger$ & & $\begin{array}{l}0 \\
0\end{array}$ & \\
\hline & & $\begin{array}{l}0 \\
0\end{array}$ & $\dagger$ & & 1,000 & \\
\hline & & 0 & & & 0 & \\
\hline & & $\begin{array}{l}10,000 \\
0\end{array}$ & & & 0 & \\
\hline & & $0^{4,000}$ & & & $\begin{array}{l}0 \\
0\end{array}$ & \\
\hline & * & $100,000,000$ & $\dagger$ & & 0 & \\
\hline & $*$ & $\begin{array}{l}0 \\
300000\end{array}$ & $t$ & & 0 & \\
\hline & * & $2,000,000$ & $\dagger$ & & 0 & \\
\hline & * & $\begin{array}{c}280,000 \\
0\end{array}$ & $t$ & $*$ & $\begin{array}{c}150,000 \\
0\end{array}$ & $t$ \\
\hline & * & 100,000 & $t$ & & 0 & \\
\hline & * & $\begin{array}{c}0 \\
16,000,000\end{array}$ & $\dagger$ & * & $\begin{array}{l}0 \\
9,100\end{array}$ & $t$ \\
\hline & & $\begin{array}{l}0 \\
0\end{array}$ & & & $\begin{array}{l}0 \\
0\end{array}$ & \\
\hline & $* \ddagger$ & $140,000,000$ & $t$ & $*$ & $3,300,000$ & \\
\hline & & $\begin{array}{c}10,000,000 \\
0\end{array}$ & $\dagger$ & & 0 & \\
\hline \multirow[t]{12}{*}{$\mathrm{C}$} & * & 110,000 & $t$ & & 0 & \\
\hline & scars & $100,000,000$ & $\dagger$ & * & 0 & $\dagger$ \\
\hline & & $\begin{array}{l}0 \\
0\end{array}$ & & & 0 & \\
\hline & * & 0 & & & 0 & \\
\hline & * & $\begin{array}{r}4,000 \\
2,300,000\end{array}$ & $\dagger$ & & $\begin{array}{l}0 \\
0\end{array}$ & \\
\hline & & 0 & & & 0 & \\
\hline & scarsł & 1,400 & $t$ & * & $\begin{array}{l}0 \\
0\end{array}$ & $\dagger$ \\
\hline & $*$ & 0 & & & 0 & \\
\hline & $\stackrel{*}{\text { scarst }^{2}}$ & $100,000,000$ & $\dagger$ & & 0 & \\
\hline & & $\begin{array}{l}0 \\
0\end{array}$ & & & $\begin{array}{l}0 \\
0\end{array}$ & \\
\hline & * & 0 & & & 0 & \\
\hline & & 0 & & & 0 & \\
\hline
\end{tabular}

* Macroscopic abscess.

$\dagger$ Unequivocal microscopic evidence of infection.

$\ddagger$ Lung abscess also, due to $E$. coli.

perimental group and 9 of the controls had minute collections of round cells, usually adjacent to blood vessels, unaccompanied by macroscopic or cultural evidence of infection, and were considered uninfected.

Occasional discrepancies between cultural and histological evidence are to be expected, since the lesions are focal, and since each kidney is divided into halves, one of which is homogenized for culture and one of which is fixed for sectioning. Also, of course, histological evidence of infection may persist indefinitely after the lesion becomes sterile.
Three of the experimentals, but none of the controls, had positive cultures of liver or lung. One of the former had an abscess of the lung.

It is apparent that the $E$. coli infection tends to "burn out" with the passage of time, since in Group B, sacrificed at one week, 9 of 22 experimentals and 2 of 21 controls had colony counts of 100,000 per $\mathrm{g}$ of kidney or greater, while in Group C, sacrificed at three weeks, only 4 of 17 experimentals and no controls had such colony counts. However, there was no significant difference in the incidence of infection between Group $\mathrm{B}$ and $\mathrm{C}$ experimentals, when the positive state of 
any one or more of the diagnostic criteria is taken to mean infection.

\section{DISCUSSION}

In a recent review of the literature (9), a total of 14 patients with potassium depletion showed evidence suggesting pyelonephritis, as judged by history, urine cultures or renal histology. In at least three of these, the pyelonephritis may have preceded the potassium depletion. The cause of the potassium depletion was primary aldosteronism in eight of the patients and was due to gastrointestinal causes in five.

In the experimental animal, there is evidence both for and against the association of pyelonephritis and potassium nephropathy. One possible explanation for this discrepancy is the fact that the use of more virulent bacteria may permit the demonstration of slight increases in susceptibility, whereas the use of less virulent bacteria would not. Since the strain of $E$. coli used in this laboratory will infect some normal rats if it is carried through a number of "passages" in rats with ligated ureters and if it is injected in large doses, it is reasonable to conclude that a relatively virulent organism is being used.

\section{SUM MARY}

Rats with acute potassium nephropathy have been shown to exhibit increased susceptibility to experimental pyelonephritis. The factor responsible for this increased susceptibility is unknown, but the authors believe that the most likely one is tubular obstruction or "internal hydronephrosis."

\section{ACKNOWLEDGMENT}

The authors wish to thank Miss Billie Sioux Bush, Miss Janet Murdock and Mrs. Frances Reed for technical assistance, and Dr. Bernard Pasternack for help with statistical analysis.

\section{REFERENCES}

1. Relman, A. S., and Schwartz, W. B. The nephropathy of potassium depletion. A clinical and pathological entity. New Engl. J. Med. 1956, 255, 195.

2. Oliver, J., MacDowell, M., Welt, L. G., Holliday, M. A., Hollander, W., Jr., Winters, R. W., Williams, T. F., and Segar, W. E. The renal lesions of electrolyte imbalance. 1. The structural alterations in potassium-depleted rats. J. exp. Med. 1957, 106, 563.

3. Eales, L., and Linder, G. C. Primary aldosteronism. Some observations on a case in a Cape Coloured woman. Quart. J. Med. 1956, 25, 539.

4. Milne, M. D., Muehrcke, R. C., and Heard, B. E. Potassium deficiency and the kidney. Brit. med. Bull. 1957, 13, 15.

5. Muehrcke, R. C., and Milne, M. D. Primary hyperaldosteronism, long-standing potassium depletion, and pyelonephritis (abstract). Clin. Res. 1957, 5, 190.

6. Woods, J. W., Welt, L. G., Hollander, W., Jr., and Newton, M. Susceptibility of rats to experimental pyelonephritis following recovery from potassium depletion. J. clin. Invest. 1960, 39, 28.

7. Carone, F. A., Kashgarian, M., and Epstein, F. H. Effect of acute potassium deficiency on susceptibility to infection with particular reference to the kidney. Yale J. Biol. Med. 1959, 32, 100.

8. Hollander, W., Jr., Winters, R. W., Williams, T. F., Bradley, J., Oliver, J., and Welt, L. G. Defect in the renal tubular reabsorption of water associated with potassium depletion in rats. Amer. J. Physiol. 1957, 189, 557.

9. Welt, L. G., Hollander, W., Jr., and Blythe, W. B. The consequences of potassium depletion. J. chron. Dis. 1960, 11, 213. 